\title{
APPLICATION OF ALLELOPATHIC PHENOMENA TO ENHANCE GROWTH AND PRODUCTION OF CAMELINA (CAMELINA SATIVA (L.))
}

\author{
AbBas, A. ${ }^{1}-$ HuAng, P. $^{1 *}-$ Hussain, S. ${ }^{2}-$ SAQIB, M. ${ }^{3}-$ He, L. ${ }^{1}-$ Shen, $F .{ }^{1}-$ Du, D. ${ }^{1 *}$ \\ ${ }^{1}$ Institute of Environment and Ecology, School of Environment and Safety Engineering, Jiangsu \\ University, Zhenjiang 212013, PR China \\ ${ }^{2}$ College of Agronomy, Northwest A \& F University, Yangling, PR China \\ ${ }^{3}$ Agronomic Research Institute, Ayub Agricultural Research Institute, Faisalabad, Pakistan \\ *Corresponding authors \\ e-mail: huangjiehp@163.com; daolindu@163.com
}

(Received $10^{\text {th }} \mathrm{Jul} 2020$; accepted $7^{\text {th }}$ Oct 2020)

\begin{abstract}
Field grown camelina suffers from various biotic and environmental stresses, affecting its growth and productivity. Allelopathy is a biochemical interaction that occurs between plants by releasing allelochemicals. It has become a sustainable approach that can help to deal with these stresses. When allelochemicals are released and applied at low concentrations, they stimulate crop growth. The potential role of allelopathy in the control of weeds, insects, and diseases is well illustrated. The use of allelopathic crops in the mulching, intercropping, and crop rotations is very useful for weed control. When released at high concentrations, these allelochemicals can also interfere with biochemical and physiological processes, thus affecting plant performance. In this review, we discuss the potential effects of allelopathy: (a) enhancing the growth performance of camelina, (b) controlling weeds, insects, and diseases, and (c) enhancing tolerance to environmental stresses. Based on previous evidence, we also discussed the mechanism, with which allelochemicals promote crop growth and confer tolerance to environmental stimuli and concluded that these allelopathic features can enhance camelina production in the future.

Keyword: allelochemicals, Camelina sativa, weed management, insect pest, abiotic stresses tolerances
\end{abstract}

\section{Introduction}

Allelopathy's definition was familiarized by plant physiologist Molisch (1937) to raise biochemical (both, inhibitory and stimulatory) interactions between all kinds of plants. Later, it was defined as the direct and indirect, beneficial or destructive effect of a plant on another plant through different compounds. These compounds are emitted from different plant parts through residual decomposition, root exudation, stem flow, and leaching into the environment (Birkett et al., 2001). The most important part of allelopathy depends on the presence of chemical compounds that are released from living or disintegrating plant parts (Dayan et al., 2000). The naturally occurring metabolites and chemicals of plants play a vital role in the processes of biologically, ecologically, and various ecosystem processes, and are interconnected with neighboring plants and the environment (Cheng and Cheng, 2015). Allelochemicals may play a role in different plants with different mechanisms of actions, and the negative and positive types of interactions are reported based on the target plant and concentration underexamined (De Albuquerque et al., 2011; Eichenberg et al., 2014). Approximately 300,000 plant species produce several kinds of secondary metabolites or compounds, but a limited proportion of these chemicals has been examined and their effects on agroecosystems and other processes in different plants have been evaluated. In allelopathy, 
the source of the compound's release into the environment (Fig. 1) is also important, and it plays a vital role in other plant processes and different agro-ecosystems (Dayan, 2006). The use of allelopathy mechanisms is conducive to crop growth and helps to increase their dominance against different problems (Inderjit, 2005).

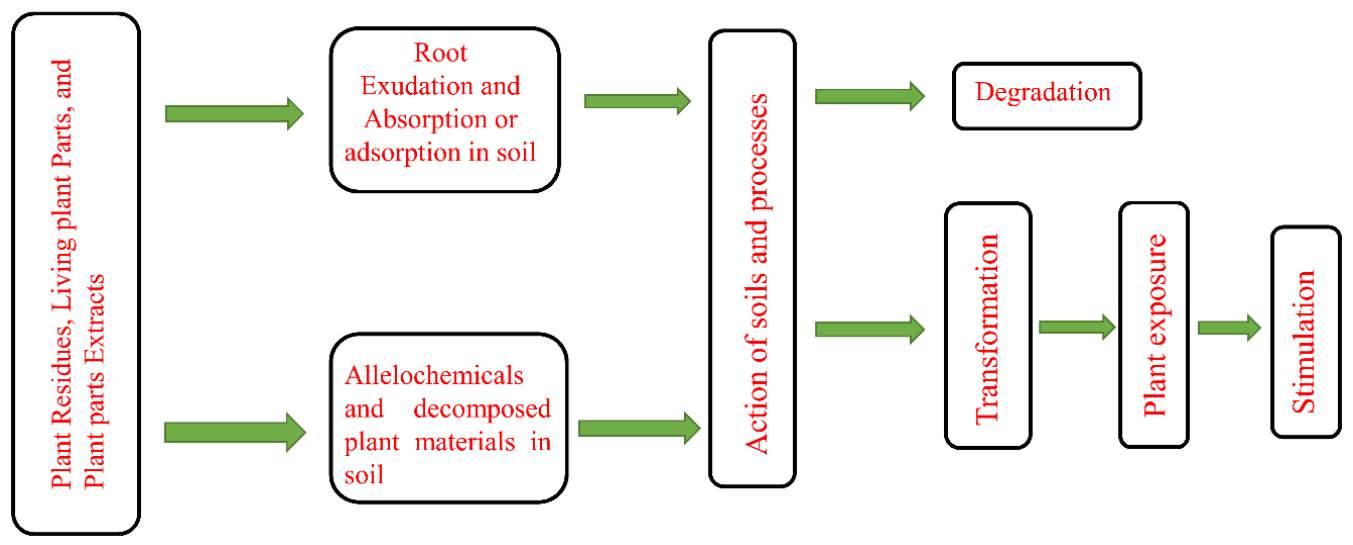

Figure 1. Allelopathy framework; chemical release into the atmosphere, after dilution reaches into the soil and available for plant roots. The leaching process may also help pant residues and extracts to reach into soil. Root intervention, absorption, root exudation, decomposition, degradation, transformation, and stimulation with plant process involve in allelopathy framework or mechanism in agriculture systems

Among the oil-seeded crops, camelina is one of the most important crops for biobased and oil production purposes. Camelina is commonly known as flax and is native to the Mediterranean regions of Europe and Asia (Obour et al., 2015; Yuan and Li, 2020). The crop is also distributed in South America, New Zealand, and Australia and appears to be adopted and perform better under cold environments (Campbell et al., 2013). Compared with other oilseed crops, it has the capability to perform better under different drought stress levels, which makes it very successful in areas with arid environments and less rainfall (Obour et al., 2015). Camelina is commonly used to produce biofuels, and bio-based products (Tabatabaie and Murthy, 2017; Kalita et al., 2018), humans (Rahman et al., 2018), and animal nutrition (Ponnampalam et al., 2019). In addition, it is used in the food industry to prevent food oxidation, loss of flavor, discoloration, and the formation of toxic compounds (Abramovic and Nikolic, 2007). Due to abiotic stresses, plant germination and growth are unreasonable, and the yields of major crops (including oilseed crops) in different countries have dropped significantly (Haq et al., 2014). Compared with other oilseed crops, camelina has several agronomic benefits because of its ability to survive in dry nature and harsh environments. However, due to abiotic stresses, there have been some promising problems from germination to harvesting (Waraich et al., 2016). In the past, researchers have also tried to evaluate the response of $C$. sativa to different abiotic stresses and other factors (fertilizers, greenhouse experiments, etc.) (Wang and Frei, 2011). Today, camelina is considered to be the most important crop in oil production, and farmers all over the world are trying to grow for good economic benefits and oil production (Keske et al., 2013). Yohannes et al. (2020) studied the consequence of salt stress (treated with $\mathrm{KCl}$ and $\mathrm{NaCl}$ ) on the germination performance of camelina and reported that salinity reduced the germination rate, depending on the salt level. Salinity also negatively 
affects seed vigor index, germination percentages, root and seedling length, which are critical for growth and yield (Amiri-Darban et al., 2020). Drought stress also possessed negative effects on camelina growth and productivity (Adam et al., 2012). Kamkar et al. (2011) demonstrated heat stress also causes a reduction in the growth and productivity of camelina. Researchers from all over the world have also tried to study the ionic effects of different abiotic stresses on different crops (Kusvuran et al., 2015; Morales et al., 2017), and conclude that $C$. sativa seedling or germination is also reduced due to different abiotic stresses (Adam et al., 2012). Nonetheless, compared with other crops, research work on camelina with their productive features under different abiotic stresses is still limited (Pavlista et al., 2015; Hunsaker et al., 2013). Aiken et al. (2015) and Pavlista et al. (2016) reported that optimal environmental conditions and normal irrigation facilities can improve the germination, seedling growth, and productivity of C. sativa.

Weeds' infestations in Camelina's growing areas are the major threats to seed yield and quality, as they are competing for lights, water, and nutrients (Berti et al., 2016; Lenssen et al., 2012). Nitrogen competition between weeds and camelina crop reduces protein content, seed yield, and fatty acid quantity; these variables show a positive response to nitrogen fertilizers (Jiang et al., 2013; Jiang and Caldwell, 2016). Moreover, chemical control is not an effective method of weed management; because camelina is tolerant to broad-leaved herbicides, and it is characterized by a narrow mode of action (Berti et al., 2016). In addition, some pre-emergence herbicides may also cause injuries to the camelina plants (Jha and Stougaard, 2013). Recently, most countries are striving to reduce the use of pesticides to meet new environmental challenges (Barzman and Dachbrodt-Saaydeh, 2011). Few studies have reported the use of zero-herbicides for weed management in oilseed crops (including $C$. sativa), such as mechanical control (Heiska, 2009) and intercropping methods (Sacuke and Ackermann, 2006). When choosing a sustainable method of weed control of $C$. sativa, the use of zero herbicides seems to be a priority in many agricultural systems. The use of allelopathy for crop improvement and weed management has been discussed for major crops (Farooq et al., 2011a). However, only a few studies have reported the use of allelopathy to improve the crop performance, and as a weed control strategy for $C$. sativa. In this review, we reveal for the first time the major problems associated with camelina cultivation and study how allopathic phenomena promote the production of camelina and respond to biotic and abiotic stresses.

\section{Crop growth promotion}

Growth enhancing effects of allelopathy for the major crops are described in the literature (Kamran et al., 2019; Ming et al., 2020); however, there is a lack of information about allelopathy in promoting the growth of $C$. sativa. Several studies were discussed, and it was found that the application of low concentrations of allelochemicals stimulates the germination process (Findura et al., 2020) and growth (Kamran et al., 2019) of the major field crops. The application of aqueous crop extracts either applied exogenously (foliar spray), and seed treatment promotes the germination and growth of crops (Farooq et al., 2018). Exogenous application of allelochemicals as a foliar spray could be approved as an effective method. According to Kamran et al. (2019) aqueous extract of sorghum (3\% and 5\%) imposed a significant improvement of seedling growth, chlorophyll content, and carotenoid protein content in maize. A recent 
study conducted by Lameirão et al. (2020), reported that low concentrations of chestnut (Castanea henryi) extract promoted seed germination, increased the seedling development, chlorophyll content, and antioxidant enzyme activity in maize. Phenolic compounds are among the important class of allelochemicals (Ameena et al., 2014), which can be applied exogenously to promote the growth of the crop. Allelopathic water extracts can increase the germination rate, improve crop stand, and seedling growth when used as a seed treatment, thereby improving plant growth (Maqbool et al., 2012). Farooq et al. (2018) reported that allelopathic water extracts, applied as a seed treatment, significantly promoted the growth, yield, and yield-related attributes in wheat (Triticum aestivum L.). moringa, sunflower (Helianthus annuus L.), sorghum, and brassica water extracts commonly used as seed treatments (Farooq et al., 2018).

Successful crop production depends largely on the optimal supply of nutrients. Soil is the basic medium that provides all essential nutrients for crop growth. Nutrients, in the form of a solution, are taken up by plant roots. Allelochemicals, when release by plant roots, greatly influences the absorption of nutrients. Under normal as well as stress conditions, allelochemicals promote nutrient uptake status by altering the nutrient forms and soil microbial populations. Allelochemicals played an important role in nutrient management because they have a great influence on biological nitrification and nutrient acquisition and in this way increase nutrients absorption (Jabran et al., 2012). Nitrogen (N) is an important macronutrient and plays an essential role in plant growth and development. Allelochemicals have significantly improved nitrogen use efficiency (NUE) by reducing $\mathrm{N}$ losses. These secondary metabolites inhibit biological nitrification by reducing the enzyme activity that plays a role in the nitrification process. Crop water extract of sorghum, sunflower, and rice (Oryza sativa L.) also have shown positive effects in this process (Farooq et al., 2013). Phenolics as an important secondary metabolite (Jabran and Farooq, 2013), promote the uptake and release Phosphorus, and Iron. Therefore, allelopathy considered a unique method to enhance crop NUE without causing environmental pollution, however, special attention needs to be paid to the camelina crop.

It is difficult to determine the mechanisms underlying the application of allelochemicals. The production of secondary metabolites by shikimic acid, malonic acid, melvonic acid, methylerythritol phosphate, and isoprenoid pathways are well documented (Taiz and Zeiger, 2010). When applied at low concentrations, secondary metabolites increased the germination rates by reducing seed dormancy, promote root growth by increasing the absorption and utilization of water and nutrients, and promote plant growth by increasing chlorophyll content, transpiration, and photosynthesis rate. Several studies also reported that the application of low concentrations of allelochemicals enhances enzyme activation (gibberellins and auxins), stimulates cell division, enhances ion absorption, and in this way increases plant growth and development.

\section{Weed management}

Camelina, also known as false flax, is an important crop of Brassicaceae and can grow successfully under various environmental conditions. However, the control of weeds is currently the main challenge for the successful camelina production (Lenssen et al., 2012; Berti et al., 2016). Weed infestation can cause severe yield reductions and quality declines, mainly through competition for lights, space, and other inputs (Jiang 
and Caldwell, 2016; Leclère et al., 2019). The major weeds of camelina are Berberis vulgaris (L.), Capsella bursa-pastoris (L.) Lepidium campestre, Thlaspi arvense (L.), Raphanus raphanistrum, Galium aparine (also known as catchweed) (Al-Shehbaz, 2012; Malhi et al., 2014; Sagun and Auer, 2017; Zhang and Auer, 2020), Camelina laxa, Camelina hispida (Zhang and Auer, 2019), Lepidium latifolium (pepper weed), Setaria faberi (foxtail) (Rizzitello et al., 2019), Cirsium arvense (field thistle), Elymus repens (L.), Matricaria recutita, Sonchus oleraceus, and Trifolium pretense (Saucke and Ackermann, 2006). Various perennial broad-leaved weeds, such as Convolvulus Arvensis (bindweed), and Chondrilla juncea (L.) (naked weed) also caused a significant reduction in camelina production. With the passage of time, the chemical control of weeds is less effective because it increases environmental pollution (Sodaeizadeh and Hosseini, 2012). In addition, the use of herbicides can also cause injuries to camelina (Leclère et al., 2019). The application of herbicides mainly causes damage to plants by reducing the efficiency of photosynthesis (Kaiser et al., 2013). Several organic alternatives to chemically controlled weeds have been reported in the literature (Macías et al., 2019; Fracchiolla et al., 2020). Allelopathy is a promising tool that can be successfully used for weeds control without causing environmental pollution and the development of herbicide resistance (Razzaq et al., 2010). Allelopathy involves the release of allelochemicals, which act as natural pesticides, can reduce environmental pollution and resistance development in weed species (Farooq et al., 2011a). Allelopathy can be successfully used for weeding of field crops through mix intercropping (Iqbal and Cheema, 2007), crop rotation (Mamolos and Kalburtji, 2001; Farooq et al., 2011a), use of ground cover and soil residue embedding, and allelopathy water extracts (Ahmad et al., 1995; Cheema et al., 2000a; Matloob et al., 2010) (Table 1). In addition, the use of smothering crops (such as rye (Secale cereals L.), buckwheat (Fagopyrum esculentum), and Black Mustard (Brassica nigra) can also be successfully used for weeds management (Jabran and Farooq, 2013). Intercropping can be an effective tool for weed management (Saudy, 2015). Various studies have shown that intercropping with allelopathic crops has been used for integrated weed management (Farooq et al., 2011a; Baumann et al., 2002). Allelopathic crops reduce the weed population by releasing allelochemicals and inhibit the weed-crop competition (Liebman and Davis, 2000; Ali et al., 2000). For example, Saucke and Ackermann (2006) reported that intercropping camelina (C. sativa) with pea (Pisum sativum L.) significantly reduce the weeds by $52-63 \%$ as compared with the sole crop. Crop rotation, temporal diversification of crops, with the inclusion of allelopathic crops can help reduce the weed population (Jabran and Farooq, 2013). In crop rotation, the allelochemicals in the rhizosphere released from the root of plants and the decomposition of previous crop residues help to suppress weeds (Voll et al., 2004; Mamolos and Kalburtji, 2001). Setaria faberi, a common weed of $C$. sativa, can be managed through crop rotations with maize-soybean, and soybean-wheat-maize (Schreiber, 1992). The use of allelopathic crops as mulching also useful for reducing the weed germination and seedling growth, by releasing of certain allelochemicals (Teasdale and Mohler, 2000; Bilalis et al., 2003; Rawat et al., 2017). Cover crops, by releasing allelochemicals, and alterations in soil physicochemical properties helpful in managing the weed population (Tursun et al., 2018). Various studies have reported the potential of allelopathic crops to reduce weeds in major crops (Cheema et al., 2000a, 2004). Therefore, there is an urgent need to classify allelopathic crops to reduce weeds in C. sativa. The use of allelopathic water extracts (aqueous extract) has caused 
widespread concern in the suppression of weeds (Farooq et al., 2020). The watersoluble allelochemicals (secondary metabolites) are first extracted in water and then used to control weeds (Bonanomi et al., 2006). Sorgaab, a water extract of sorghum, is one of the most commonly used water extracts for weed control (Cheema et al., 2002a). The application of sorgaab for suppressing of weeds in major crops such as wheat, cotton (Gossypium hirsutum L.), rice, and maize (Iqbal et al., 2009; Cheema et al., 2004), have been well reported. The sunflower water extract is rich in chlorogenic, ferulic acid, and vanillic acids (Ghafar et al., 2001), and has the potential to inhibit the growth of grassy and broadleaf weeds (Anjum and Bajwa, 2010). The combined application of various allelopathic water extracts may have more benefits in controlling weeds, as compared with the sole application (Cheema et al., 2003; Jamil et al., 2009). Different crops have released specific types of allelochemicals, and each allelochemical has control of a specific type of weed. Gramine/Hordenine, well-known allelochemicals, can inhibit the growth of Capsella bursa-pastoris (the major weed of C. sativa) (Nawaz et al., 2014). The mechanisms underlying the control of weeds through allelopathy are not well understood. Some reports have discussed that the application of high concentrations of allelochemicals may interfere with cell division, hormonal balancing, mineral absorption and transport, plant water relations, oscillations of stomata, membrane permeability, respiration and photosynthesis, and the process of protein metabolism (Gupta et al., 2018; Nawaz et al., 2018). This phytotoxic activity of allelochemicals can inhibit the growth of weeds.

Table 1. The application of allelopathy for the suppression of weeds in different crops

\begin{tabular}{|c|c|c|c|}
\hline Weed species & Allelopathic source & Weed control (\%) & Reference \\
\hline \multirow{4}{*}{$\begin{array}{l}\text { Convolvulus } \\
\text { arvensis }\end{array}$} & $\begin{array}{c}\text { Allelopathic water extracts } \\
\text { Sunflower (Helianthus annuus } \\
\text { L.) }\end{array}$ & $\begin{array}{l}\text { Reduction in total weed } \\
\text { density and DW } \\
(17.19 \% \text { and } 35.92 \%, \\
\text { respectively) }\end{array}$ & $\begin{array}{l}\text { Naseem et al. } \\
\qquad(2010)\end{array}$ \\
\hline & $\begin{array}{c}\text { Allelopathic water extracts } \\
\text { Sorghum (Sorghum bicolor L.) }\end{array}$ & $\begin{array}{c}\text { Reduction in total weed } \\
\text { density and DW (by } 31.58 \% \\
\text { and } 44.11-59.62 \%, \\
\text { respectively) }\end{array}$ & $\begin{array}{l}\text { Khaliq et al. } \\
\text { (2002); Cheema et } \\
\text { al. (2001) }\end{array}$ \\
\hline & $\begin{array}{l}\text { Allelopathic crop rotations } \\
\text { (Sorghum (surface mulch) }\end{array}$ & $\begin{array}{l}\text { Reduction in total weed DW } \\
\qquad(81 \%)\end{array}$ & $\begin{array}{l}\text { Cheema et al. } \\
\text { (2000b) }\end{array}$ \\
\hline & $\begin{array}{l}\text { Combine application of } \\
\text { allelopathic water extracts and } \\
\text { herbicides Sorghum }\left(10 \mathrm{~L} \mathrm{ha}^{-1}\right) \\
+ \text { S. metolachlor }\left(2.3 \mathrm{~kg} \text { a.i. } \mathrm{ha}^{-1}\right. \\
\text { Dualgold } 960 \mathrm{EC})\end{array}$ & $\begin{array}{l}\text { Reduction in total weed DW } \\
\qquad(79.32 \%)\end{array}$ & Khaliq et al. (2002) \\
\hline Setaria faberi & $\begin{array}{l}\text { Maize-soybean, and soybean- } \\
\text { wheat-maize }\end{array}$ & $\begin{array}{l}\text { Completely inhibit the weed } \\
\text { growth }\end{array}$ & Schreiber (1992) \\
\hline $\begin{array}{c}\text { Capsella bursa- } \\
\text { pastoris }\end{array}$ & $\begin{array}{c}\text { Allelochemicals application of } \\
\text { Gramine/Hordenine }\end{array}$ & $\begin{array}{c}\text { Inhibited the weed density and } \\
\text { biomass }\end{array}$ & Nawaz et al. (2014) \\
\hline $\begin{array}{l}\text { Major weeds of } \\
\text { C. sativa }\end{array}$ & $\begin{array}{l}\text { Allelopathic intercropping with } \\
\text { Camelina (C. sativa) with pea } \\
\text { (Pisum sativum L.) }\end{array}$ & Reduce the weeds by $52-63 \%$ & $\begin{array}{c}\text { Saucke and } \\
\text { Ackermann (2006) }\end{array}$ \\
\hline
\end{tabular}




\section{Pest and disease management}

Camelina sativa is an important source of biodiesel and classified as a minor crop (Sobiech et al., 2020). In the cultivation of minor crops, insects and diseases can cause serious harm to growth, yield, and yield-related aspects (Olivier et al., 2011; Meynard et al., 2018). Many types of insects, such as Lygus hesperus Knight (Naranjo and Stefanek, 2012), Lygus spp. (Naranjo et al., 2011), Phyllotreta cruciferae, Ceutorhyncus obstructs), and Meligethes aeneus (Scottish Rural Colleges, 2013) are regarded as pests of camelina crop. Some other types such as Ceutorhynchus cyanipennis and C. americanus also caused damaging effects for camelina crop (Malik et al., 2018). In addition, various diseases, such as Leptosphaeria maculans, Sclerotinia, Peronospora, Botrytis sclerotinia, Ustilago, aster yellows (Olivier et al., 2011; Soroka et al., 2015) and Sclerotinia sclerotiorum (Ehrensing and Guy, 2008) are among the important diseases of camelina causing a severe reduction in growth, and yield losses. Camelina sativa is also susceptible to other diseases such as damping-off, white rust, and downy mildew (Séguin-Swartz et al., 2009). Recently, to reduce pest populations, the most reliance is on the use of pesticides. Although chemical pest control methods have made significant contributions to improving crop performances, certain challenges are also associated with them. The increasing cost of pesticides, environmental concerns, and resistance against pesticides are among the major challenge for using pesticides for pest control (Farooq et al., 2013). A number of options are available for reducing insect populations and disease control without any environmental hazards. Reducing the pest population through the allelopathic phenomenon is included among the innovative pest control methods (Nawaz et al., 2018). Neem (Azadirachta indica L.) is rich in azadirachtin and is the most commonly used to reduce insect populations (Khan et al., 2014). The application of some types of allelochemicals extracted from Chenopodium ficifolium (Dang et al., 2010), and Eucalyptus globulus (Farooq et al., 2011a) are among the allelopathic measures used for controlling the insect populations. Allelochemicals also were shown their role to reduce damage to plant diseases (Nawaz et al., 2018). Aqueous extracts of many allelopathic plants are known to revelation antifungal and antibacterial possessions. According to Bajwa et al. (2004), the water extract of Parthenium (Parthenium hysterophorus) exhibited antifungal activity against fungal diseases. Momilactone A and momilactone B are important allelochemicals in rice and play a role in suppressing fungal and bacterial diseases (Kong et al., 2004). For major crops, antifungal and antibacterial activities of allelochemicals are well understood but their effectiveness against camelina-specific diseases remains to be further explored.

\section{Abiotic stress tolerance}

As an annual crop, $C$. sativa can adopt under a wide range of environmental conditions (Hunsaker et al., 2011; Schillinger et al., 2012). However, under field conditions, the crop is also pronounced to various abiotic stresses (Schillinger et al., 2012; Gesch, 2014; Gesch and Cermak, 2011), which retard the growth, and yield losses (Berti et al., 2011). Some studies have reported complete crop failure under abiotic stress conditions. Among abiotic stress, high temperature (Gesch, 2014; Schillinger et al., 2012), drought stress (Eberle et al., 2015), salinity stress (Khalid et al., 2015; Heydarian et al., 2018), and waterlogging (Gesch and Cermak, 2011) are among major limiting factors for camelina growth and its production. Various researchers have been 
documented the optimum temperature ranges for better emergence and growth of $C$. sativa. Russo et al. (2010) recorded $100 \%$ germination at $4{ }^{\circ} \mathrm{C}, 10^{\circ} \mathrm{C}, 16^{\circ} \mathrm{C}, 21{ }^{\circ} \mathrm{C}$, and $27^{\circ} \mathrm{C}$. They also reported that the temperature above $32{ }^{\circ} \mathrm{C}$ might decline the germination rates. According to Gesch (2014), high temperature has resulted in the decrement of seed yield and oil content of $C$. sativa, even under optimal water conditions. Similar findings were also reported by (Schillinger et al., 2012), unveiled that high temperature significantly hinders the seed yield of $C$. sativa. Allelopathy has great potential to enhance crop tolerance to cope with environmental stresses (Fig. 2). Farooq et al. (2018) reported that the application of crop water extracts (through seed priming or foliar spray application) significantly promoted wheat growth and yieldrelated aspects under heat stress. The increase in growth and yield attributed to the decrease in MDA content and membrane leakage under heat stress.

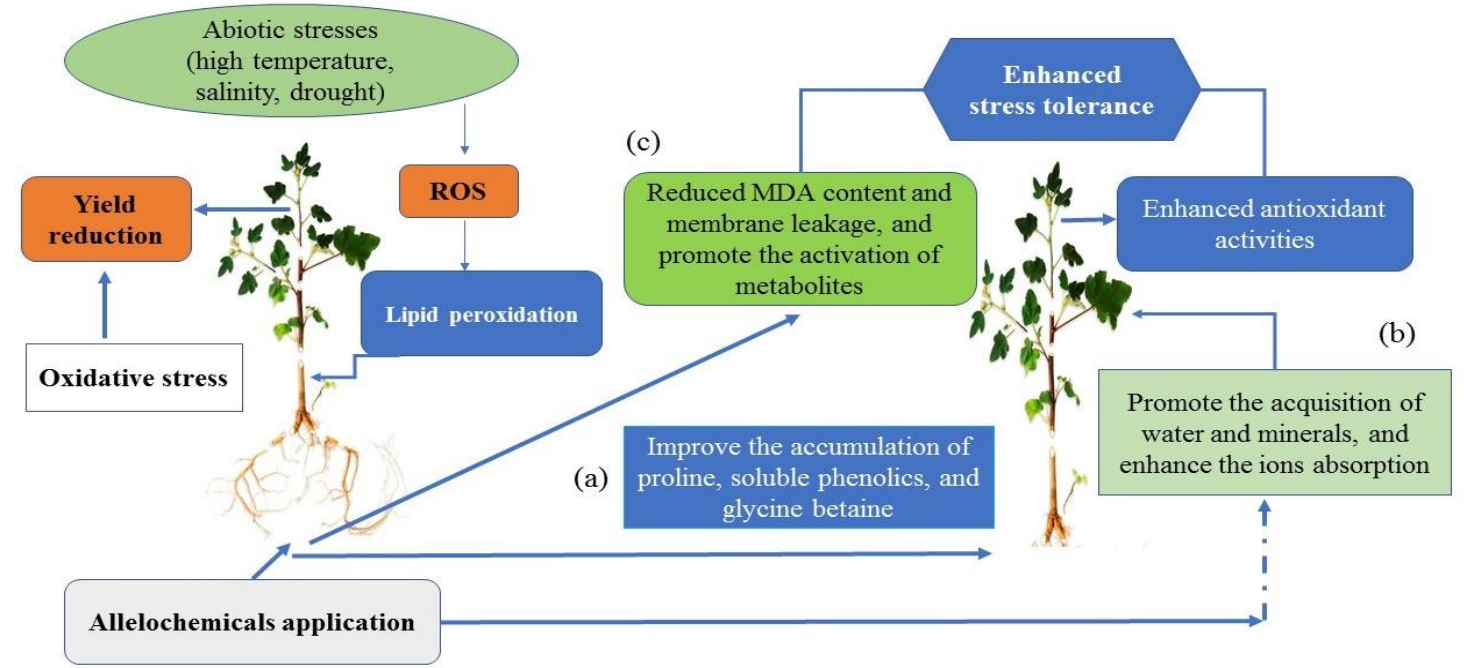

Figure 2. Application of allelochemicals to enhance the tolerance against abiotic stresses. Allelochemicals; applied at low concentrations, (a) improve the accumulation of proline, soluble phenolic, and glycine betaine, (b) promote the acquisition of water and minerals, and enhance the ions absorption. Under stress conditions, allelochemicals (c) reduce the malondialdehyde (MDA) content and membrane leakage and promote the activation of metabolites

Khalid et al. (2015) reported that salinity stress results in postponed germination, decrease seedling emergence, plant growth (plant height), relative water content, and chlorophyll (CHL) contents (CHL $a, b$ and total CHL) in $C$. sativa. The higher concentration of $\mathrm{Na}^{+}$and $\mathrm{Cl}^{-}$in chloroplast are resulted in a reduction in photosynthesis. In addition, salinity also causes an increment in electric conductivity (52.8\%), guiacol peroxidase, and malondialdehyde content in stressed camelina plants as compared with untreated plants. Similarly, Morales et al. (2017) found reduced germination, plant growth, chlorophyll content, and stomatal size in camelina depending on cultivars and salinity levels. In the same study, increased proline content was also reported with increasing salinity levels. In a recent study, Yohannes et al. (2020) demonstrated that salt stress (with $\mathrm{KCl}$ and $\mathrm{NaCl}$ ) can be caused a marked reduction in germination attributes (such as germination speed, germination percentage, and index), root and shoot length, root shoot ratio, and fresh weights of Camelina seedling depending on 
stress level. Farooq et al. (2011b) explored the role of allelopathy in enhancing resistance to salinity. In this regard, the authors reported that seed priming with sunflower water extract could not only increase the germination rate but also increase seedling growth. Wang et al. (2019) studied the effect of goldenrod (Solidago canadensis) leaf extract on lettuce (Lactuca sativa L.) and reported that at low concentrations goldenrod extract promotes root growth and leaf width under high salt concentrations. One possible mechanism is that at low concentration, the allelochemicals released by goldenrod leaf extracts can produce the reactive oxygen molecules in plant cells, and then have a positive effect on the seed germination and seedling growth of lettuce (Prithiviraj et al., 2007).

Drought is another abiotic stress imposed negative effects on the growth and productivity of $C$. sativa. In this regard, Ahmed et al. (2017) reported that drought stress resulted in decreasing growth attributes (length, and dry and fresh weights of the root and shoot), photosynthetic and transpiration rates, leaves stomatal conductance, and soluble proteins content in treated camelina plant as compared with untreated one. In the same study, an increment in proline content, soluble sugars, and amino acid content was also reported under drought stress. Similarly, Waraich et al. (2017) demonstrated that water deficit conditions (60\% field capacity (FC)) resulted in decreasing leaf area index, crop growth rates, leaf area duration, net assimilation rates, and yield-related attributes (1000-seed weight, and seed yield) in camelina as compared to normally irrigated plants (100\% FC). In a recent study, Gao et al. (2018) have documented the decreased photosynthesis and transpiration rates, stomatal conductance, and root and shoot biomass of camelina under water deficit conditions. Farooq et al. (2018) reported that crop water extracts (applied through seed priming or foliar spray) promote the growth, yield, and yield-related aspects in wheat, subjected to drought stress. The improvement was attributed to the reduced MDA contents and membrane leakage under drought stress.

Under stress conditions, allelopathic substances (secondary metabolites) play a vital role in the production of reactive oxygen species (ROS) at first, and then in the activation of the antioxidant defense system (Farooq et al., 2013). In addition, these substances also promote the acquisition of water and minerals, chloroplast function, the activation of metabolites, and enhance the absorption of ions (Waśkiewicz et al., 2013), thus playing an active role in the defense system. Moreover, allelochemicals can also produce hormonal imbalance, which can lead to the overproduction of some useful hormones, which is crucial for the smooth operation of different physiological processes under stress. Allelochemicals also improve the accumulation of proline, soluble phenolic, and glycine betaine, which may lead to the stabilize of the biological membrane under stress conditions (Farooq et al., 2018). The increased allelochemicalsinduced activities of antioxidant enzymes also responsible for stress tolerance (Ye et al., 2006).

The enhancement of abiotic stress tolerance using allelopathic phenomena has been reported for major crops. However, reports on the use of allelopathy to enhance stress tolerance in camelina are limited and further studies are needed.

\section{Limitations and implementations}

Allelochemicals are mainly composed of secondary metabolites with different natural pathways (Fig. 1) and some allelochemicals change the process during 
extraction. Therefore, researchers must carefully determine whether plants haves allelopathic potential or separate and identify allelochemicals using organic solvents and aqueous extracts from plant tissues. The type and quantity of allelochemicals released into the environment depend on the combined effects of the plant itself (plant factors) and environmental factors (De Albuquerque et al., 2010). Plants from the same environment or close in taxonomy do not necessarily show similar secondary metabolites production, so they may not secrete the same quantity and quality of allelochemicals or have similar allelopathic effects (Chon and Nelson, 2010). A large number of studies have shown that allelopathy has good application potential in agricultural production. So far, many allelopathic crops have been used in agricultural production, but their application is limited to small-scale and regional areas. In nature, plant products represent a vast diversity of compounds with a variety of biological activity (Inderjit, 2005). The natural products represent a diverse class of chemical compounds. These allelochemicals will have an impact on different species of plants. There are limitations to the successful use of allelochemicals in weed management. In implementing of natural products to effective weed/pest management, some of these factors include: (i) the concentration of the compounds is very low, (ii) the half-life of allelochemicals is usually very short, (iii) the weed selectivity is narrow, and (v) highcost production.

\section{Conclusion and future prospects}

This review for the first time highlights the potential of allelopathy to promote the growth of camelina plants, as well as the potential to control weeds, insects, and diseases of $C$. sativa. When applied at low concentrations, allelochemicals can reduce seed dormancy, increase water and nutrient absorption; improve photosynthesis and respiration rate, thereby promoting germination, root, and plant growth. The use of allelopathic crops in the form of cover crops, mulching, and including in crop rotations can be useful in weed management. Correspondingly, studies to date have shown that allelochemicals have great potential in controlling of insects and diseases.

In the past, most research was on the use of allelopathy on major crops, but a lot of work needs to be done on camelina. Future research should be carried out: (a) to establish the feasible technique of using allelochemicals for camelina under field experimentation, (b) to study the definite mechanisms related to enhancing the growth of camelina (c) to illustrate the optimum concentrations of allelochemicals for promoting the growth and development in camelina, (d) to screen the diverse range of crops with greater pest-suppress ability, and (e) to find the advance biotechnological tools to enhance biological weed/pest control in camelina.

Acknowledgments. This work was supported by the National Natural Science Foundation of China (31200316, 31770446), Senior Talent Fund of Jiangsu University (11JDG150), China Postdoctoral Science Foundation (2012M520999), the State Key Research Development Program of China (2017YFC1200100).

Conflict of interests. Authors declare that there is not any conflict of interests. 


\section{REFERENCES}

[1] Abramovic, H., Butinar, B., Nikolic, V. (2007): Changes occurring in phenolic content, tocopherol composition and oxidative stability of Camelina sativa oil during storage. Food Chem 104: 903-909.

[2] Adam, H. D., Luce, C. H., Breshears, D. D., Allen, C. D., Weiler, M., Hale, V. C., Smith, A. M. S., Huxman, T. E. (2012): Ecohydrological consequences of drought- and infestation- triggered tree die-off: insights and hypotheses. - Ecohydrol 5: 145-159.

[3] Ahmad, S., Rehman, A., Cheema, Z. A., Tanveer, A., Khaliq, A. (1995): Evaluation of some crop residues for their allelopathic effects on germination and growth of cotton and Cottonweeds. - 4th Pakistan Weed Science Conference, Faisalabad, pp. 63-71.

[4] Ahmed, Z., Waraich, E. A., Rashid, A., Shahbaz, M. (2017): Morpho-physiological and biochemical responses of camelina (Camelina sativa crantz) genotypes under drought stress. - Int J Agric Biol 19: 1-7.

[5] Aiken, R., Baltensperger, D., Krall, J., Pavlista, A., Johnson, J. (2015): Planting methods affect emergence, flowering and yield of spring oilseed crops in the US Central High Plains. - Industrial Crops and Products 69: 273-277.

[6] Ali, Z., Malik M. A., Cheema M. A. (2000): Studies on determining a suitable canolawheat intercropping pattern. - Int J Agric Biol 2: 42-44.

[7] Al-Shehbaz, I. A. (2012): A generic and tribal synopsis of the Brassicaceae (Cruciferae). - Taxon 61: 931-954.

[8] Ameena, M., Geethakumari, V. L., Sansamma, G. (2014): Allelopathic influence of purple nutsedge (Cyperus rotundus L.) root exudates on germination and growth of important field crops. - Int J Agric Sci 10: 186-189.

[9] Amiri-Darban, N., Nourmohammadi, G., Shirani Rad, A. H., Mirhadi, S. M. J., Majidi H. I. (2020): Potassium sulfate and ammonium sulfate affect quality and quantity of camelina oil grown with different irrigation regimes. - Ind Crops Prod 148: 112308.

[10] Anjum. T., Bajwa, R. (2010): Sunflower phytochemicals adversely affect wheat yield. Natural Product Res 24: 825-837.

[11] Bajwa, R., Shafique, S., Anjum, T., Shafique, S. (2004): Antifungal activity of allelopathic plant extracts IV: growth response of Drechslera hawaiiensis, Alternaria alternata and Fusarium monilifrome to aqueous extract of Parthenium hysterophorus. Int J Agric Sci 6: 511-516.

[12] Barzman, M., Dachbrodt-Saaydeh, S. (2011): Comparative analysis of pesticide action plans in five European countries. - Pest Manage Sci 67: 1481-1485.

[13] Baumann, D. T., Bastiaans, L., Kropff, M. J. (2002): Intercropping system optimization for yield, quality, and weed suppression combining mechanistic and descriptive models. Agron J 94: 734-742.

[14] Berti, M., Wilckens, R., Fischer, S., Solis, A., Johnson, B. (2011): Seeding date influence on camelina seed yield, yield components, and oil content in Chile. - Ind Crops Prod 34: 1358-1365.

[15] Berti, M., Gesch, R., Eynck, C., Anderson, J., Cermak, S. (2016): Camelina uses, genetics, genomics, production, and management. - Ind Crops Prod 94: 690-710.

[16] Bilalis, D., Sidiras, N., Economou, G., Vakali, C. (2003): Effect of different levels of wheat straw soil surface coverage on weed flora in Vicia faba crops. - J Agron Crop Sci 189: 233-241.

[17] Birkett, M. A., Chamberlain, K., Hooper, A. M., Pickett, J. A. (2001): Does allelopathy offer real promise for practical weed management and for explaining rhizosphere interactions involving higher plants? - Plant Soil 232: 31-39.

[18] Bonanomi, G., Sicurezza, M. G., Caporaso, S., Esposito, A., Mazzoleni, S. (2006): Phytotoxicity dynamics of decaying plant materials. - New Phytol 169: 571-578. 
[19] Campbell, M. C., Rossi, A. F., Erskine, W. (2013): Camelina (Camelina sativa (L.) Crantz): agronomic potential in Mediterranean environments and diversity for biofuel and food uses. - Crop Pasture Sci 64: 388-398.

[20] Cheema, Z. A., Asim, M., Khaliq A (2000a): Sorghum allelopathy for weed control in cotton (Gossypium arboretum L.). - Int J Agric Biol 2: 37-40.

[21] Cheema, Z. A., Rakha, A., Khaliq, A. (2000b): Use of sorghum water extract and sorghum mulch for weed management in mungbean. - Pak J Agri Sci 37: 140-144.

[22] Cheema, Z. A., Khaliq, A., Akhtar S (2001): Use of sorghum water extract (sorghum water extract) as a natural weed inhibitor in spring mungbean. - Int J Agric Biol 3: 515518.

[23] Cheema, Z. A., Iqbal, M., Ahmad, R. (2002a): Response of wheat varieties and some rabi weeds to allelopathic effects of sorghum water extract. - Int J Agric Biol 4: 52-55.

[24] Cheema, Z. A., Khaliq, A., Ali K. (2002b): Efficacy of Sorgaab for weed control in wheat grown at different fertility levels. - Pak J Weed Sci Res 8: 33-38.

[25] Cheema, Z. A., Khaliq, A., Mubeen, M. (2003): Response of wheat and winter weeds to foliar application of different plant water extracts of sorghum (S. bicolor). - Pak J Weed Sci Res 9: 89-97.

[26] Cheema, Z. A., Khaliq, A., Saeed, S. (2004): Weed control in maize (Zea mays L.) through sorghum allelopathy. - J Sustain Agri 23: 73-86.

[27] Cheng, F., Cheng, Z. (2015): Research Progress on the use of Plant Allelopathy in Agriculture and the Physiological and Ecological Mechanisms of Allelopathy. - Front Plant Sci 6.

[28] Dang, Q. L., Lee, G. Y., Choi, Y. H., Choi, G. J., Jang, K. S., Park, M. S., Soh, H. S., Han, Y. H., Lim, C. H., Kim, J. C. (2010): Insecticidal activities of crude extracts and phospholipids from Chenopodium ficifolium against melon and cotton aphid, Aphis gossypii. - Crop Protec 29: 1124-1129.

[29] Dass, A., Shekhawat, K., Choudhary, A. K., Sepat, S., Rathore, S. S., Mahajan, G., Chauhan, B. S. (2017): Weed management in rice using crop competition-a review. Crop Protection. 95: 45-52.

[30] Dayan, F. E. (2006): Factors modulating the levels of the allelochemical sorgoleone in Sorghum bicolor. - Planta 224: 339-346.

[31] Dayan, F. E., Romagni, J. G., Duke, S. O. (2000): Investigating the mode of action of natural phytotoxins. - J Chem Ecol 26: 2079-2094.

[32] De Albuquerque, M. B., Santos, R. C., Lima, L. M., Melo Filho, P. A., Nogueira, R. J. M. C., Da Câmara, C. A. G., Ramos, A. R. (2011): Allelopathy, an alternative tool to improve cropping systems. A review. - Agron Sustain Develop 31: 379-395.

[33] Eberle, C. A., Thom, M. D., Nemec, K. T., Forcella, F., Lundgren, J. G., Gesch, R. W., Riedell, W. E., Papiernik, S. K., Wagner, A., Peterson, D. H. (2015): Using pennycress, camelina, and canola cash cover crops to provision pollinators. - Ind Crops Prod 75: 2025 .

[34] Ehrensing, D. T., Guy, S. O. (2008): Oilseed Crops: Camelina. - Oregon State University Extension Service EM, 8953.

[35] Eichenberg, D., Ristok, C., Kroeber, W., Bruelheide, H. (2014): Plant polyphenols implications of different sampling, storage and sample processing in biodiversityecosystem functioning experiments. - Chem Ecol 30: 676-692.

[36] Farooq, M., Jabran, K., Cheema, Z. A., Wahid, A., Siddique, K. H. M. (2011a): The role of allelopathy in agricultural pest management. - Pest Manage Sci 67: 493-506.

[37] Farooq, M., Habib, M., Rehman, A., Wahid, A., Munir, R. (2011b): Employing aqueous allelopathic extracts of sunflower in improving salinity tolerance in rice. - J Agric Soc Sci 7: 75-80.

[38] Farooq, M., Bajwa, A. A., Cheema, S. A., Cheema, Z. A. (2013): Application of allelopathy in crop production. - Int J Agric Biol 15: 1367-1378. 
[39] Farooq, M., Nadeem, F., Arfat, M. Y., Nabeel, M., Musadaq, S., Cheema, S. A., Nawaz, A. (2018): Exogenous application of allelopathic water extracts helps improving tolerance against terminal heat and drought stresses in bread wheat (Triticum aestivum L. Em. Thell.). - J Agron Crop Sci 204: 298-312.

[40] Farooq, N., Abbas, T., Tanveer, A., Jabran, K. (2020): Allelopathy for Weed Management. - In: Mérillon, J.-M., Ramawat, K. G. (eds.) Co-evolution of Secondary Metabolites. Springer, Cham, pp. 505-519.

[41] Findura, P., Hara, P., Szparaga, A., Kocira, S., Czerwińska, E., Bartoš, P., Nowak, J., Treder, K. (2020): Evaluation of the effects of allelopathic aqueous plant extracts, as potential preparations for seed dressing, on the modulation of cauliflower seed germination. - Agriculture 10(4): 122.

[42] Fracchiolla, M., Renna, M., D’Imperio, M., Lasorella, C., Santamaria, P., Cazzato, E. (2020): Living mulch and organic fertilization to improve weed management, yield and quality of broccoli raab in organic farming. - Plants 9(2): p.177.

[43] Gao, L., Caldwell, C. D., Jiang, Y. (2018): Photosynthesis and growth of Camelina and canola in response to water deficit and applied nitrogen. - Crop Sci 58: 393-401.

[44] Gesch, R. W. (2014): Influence of genotype and sowing date on Camelina growth and yield in the north central US. - Ind Crops Prod 54: 209-215.

[45] Gesch, R., Cermak, S. (2011): Sowing date and tillage effects on fall-seeded camelina in the northern Corn Belt. - Agronomy Journal 103: 980-987.

[46] Ghafar, A., Saleem, B., Haq, A., Qureshi, M. J. (2001): Isolation and identification of allelochemicals of sunflower (Helianthus annuus L.). - Int J Agri Biol 3: 21-22.

[47] Gupta, D. K., Palma, J. M., Corpas, F. J. eds. (2018): Antioxidants and Antioxidant Enzymes in Higher Plants. - Springer, Cham.

[48] Haq, T., Ali, A., Nadeem, S. M., Maqbool, M., Ibrahim. M. (2014): Performance of canola cultivars under drought stress induced by withholding irrigation at different growth stages. - Soil \& Environ 33: 43-50.

[49] Heiska, S. (2009): Developing Weed Control Methods for Camelina: A Newly Introduced, High-Value Oil Seed Crop. - In: Kingely, R. V. (ed.) Weeds: Management, Economic Impacts and Biology. - Nova Science Publishers, New York, pp. 41-59.

[50] Heydarian, Z., Yu, M., Gruber, M., Coutu, C., Robinson, S. J., Hegedus, D. D. (2018): Changes in gene expression in Camelina sativa roots and vegetative tissues in response to salinity stress. - Sci Rep 8(1): 1-22.

[51] Hunsaker, D., French, A., Clarke, T., El-Shikha, D. (2011): Water use, crop coefficients, and irrigation management criteria for Camelina production in arid regions. - Irrig Sci 29: 27-43.

[52] Hunsaker, D. J., French, A. N., Thorp, K. R. (2013): Camelina water use and seed yield response to irrigation scheduling in an arid environment. - Irrig Sci 31: 911-929.

[53] Inderjit (2005): Soil microorganisms: an important determinant of allelopathic activity. Plant Soil 274: 227-236.

[54] Iqbal, J., Cheema, Z. A. (2007): Effect of allelopathic crops water extracts on glyphosate dose for weed control in Cotton (Gossypium hirsutum L.). - Allelopathy J 19: 403-410.

[55] Iqbal, J., Cheema, Z. A., Mushtaq, M. N. (2009): Allelopathic crop water extracts reduce the herbicide dose for weed control in cotton (Gossypium hirsutum). - Int J Agric Biol 11: 360-366.

[56] Jabran, K., Chauhan, B. S. (2018): Overview and Significance of Non-chemical Weed Control. - In: Jabran, K., Chauhan, B. S. (eds.) Non-chemical Weed Control. 1st Ed. Elsevier, New York, pp. 1-8.

[57] Jabran, K., Farooq, M. (2013): Implications of Potential Allelopathic Crops in Agricultural Systems. - In: Cheema, Z. A., Farooq, M., Wahid, A. (eds.). Allelopathy: Current Trends and Future Applications. Springer, Berlin, pp, 349-385. 
[58] Jabran, K., Farooq, M., Aziz, T., Siddique, K. H. M. (2012): Allelopathy and Crop Nutrition. - In: Cheema, Z. A., Farooq, M., Wahid, A. (eds.). Allelopathy: Current Trends and Future Applications. Springer, Berlin, pp. 113-143.

[59] Jabran, K., Mahajan, G., Sardana, V., Chauhan, B. S. (2015): Allelopathy for weed control in agricultural systems. - Crop Protec 72: 57-65.

[60] Jamil, M., Cheema, Z. A., Mushtaq, M. N., Farooq, M., Cheema, M. A. (2009): Alternative control of wild oat and canary grass in wheat fields by allelopathic plant water extracts. - Agron Sustain Dev 29: 475-482.

[61] Jha, P., Stougaard, R. N. (2013): Camelina (Camelina sativa) tolerance to selected preemergence herbicides. - Weed Techol 27: 712-717.

[62] Jiang, Y., Caldwell, C. D. (2016): Effect of nitrogen fertilization on Camelina seed yield, yield components, and downy mildew infection. - Cand J Plant Sci 96: 17-26.

[63] Jiang, Y., Caldwell, C. D., Falk, K. C., Lada, R. R., MacDonald, D. (2013): Camelina yield and quality response to combined nitrogen and sulfur. - Agron J 105: 1847-1852.

[64] Kaiser, Y. I., Menegat, A., Gerhards, R. (2013): Chlorophyll fluorescence imaging: a new method for rapid detection of herbicide resistance in Alopecurus myosuroides. - Weed Res 53: 399-406.

[65] Kalita, D. J., Tarnavchyk, I., Sibi, M., Moser, B. R., Webster, D. C., Chisholm, B. J. (2018): Biobased poly (vinyl ether) derived from soybean oil, linseed oil, and camelina oil: synthesis, characterization, and properties of crosslinked networks and surface coatings. - Prog Organic Coat 125: 453-462.

[66] Kamkar, B., Daneshmand, A. R., Ghooshchi, F., Shiranirad, A. H., Safahani Langeroundi, A. R. (2011): The effects of irrigation regimes and nitrogen rates on some agronomic traits of canola under a semiarid environment. - Agric Water Manage 98: 1005-1012.

[67] Kamran, M., Cheema, Z. A., Farooq, M., Ali, Q., Anjum, M. Z., Raza, A. (2019): Allelopathic influence of sorghum aqueous extract on growth, physiology and photosynthetic activity of maize (Zea mays L.) seedling. - Philipp Agric Sci 102: 33-41.

[68] Keske, C. M. H., Hoag, D. L., Brandess, A., Johnson, J. J. (2013): Is it economically feasible for farmers to grow their own fuel? A study of Camelina sativa produced in the western United States as an on-farm biofuel. - Biomass Bioenerg 54: 89-99.

[69] Khalid, H., Kumari, M., Grover, A., Nasim, M. (2015): Salinity stress tolerance of camelina investigated in vitro. - Sci Agric Bohem 46: 137-144.

[70] Khaliq, A., Aslam, Z., Cheema, Z. A. (2002): Efficacy of different weed management strategies in mungbean (Vigna radiata L.). - Int J Agric Biol 4: 237-239.

[71] Khan, A. A., Afzal, M., Qureshi, J. A., Khan, A. M., Raza A. M. (2014): Botanicals, selective insecticides, and predators to control Diaphorina citri (Hemiptera: Liviidae) in citrus orchards. - Int Sci 21: 717-726.

[72] Kong, C., Liang, W., Xu, X., Hu, F., Wang, P., Jiang, Y. (2004): Release and activity of allelochemicals from allelopathic rice seedlings. - J Agric Food Chem 52: 2861-2865.

[73] Kusvuran, A., Nazli, R. I., Kusvuran, S. (2015): The effects of salinity on seed germination in perennial ryegrass (Lolium perenne L.) varieties. - J Agric Na Sci 2: 7884.

[74] Lameirão, F., Pinto, D. F., Vieira, E. F., Peixoto, A., Freire, C., Sut, S., Rodrigues, F. (2020): Green-sustainable recovery of phenolic and antioxidant compounds from industrial chestnut shells using ultrasound-assisted extraction. Optimization and evaluation of biological activities in vitro. - Antioxidants 9(3): 267.

[75] Leclère, M., Jeuffroy, M. H., Butier, A., Chatain, C., Loyce, C. (2019): Controlling weeds in camelina with innovative herbicide-free crop management routes across various environments. - Ind Crops Prod 140: p.111605.

[76] Lenssen, A. W., Iversen, W. M., Sainju, U. M., Caesar-Tonthat, T. C., Blodgett, B. L., Allen, B. L., Evans, R. G. (2012): Yield, pests, and water use of durum and selected crucifer oilseeds in two-year rotations. - Agronomy J 104: 1295-1304. 
[77] Liebman, M., Davis, A. S. (2000): Integration of soil, crop, and weed management in low-external- input farming systems. - Weed Res 40: 27-47.

[78] Macías, F. A., Mejías, F. J., Molinillo, J. M. (2019): Recent advances in allelopathy for weed control: from knowledge to applications. - Pest Manage Sci 75: 2413-2436.

[79] Malhi, S. S., Johnson, E. N., Hall, L. M., May, W. E., Phelps, S., Nybo, B. (2014): Effect of nitrogen fertilizer application on seed yield, $\mathrm{N}$ uptake, and seed quality of Camelina sativa. - Cand J Soil Sci 94: 35-47.

[80] Malik, M. R., Tang, J., Sharma, N. et al. (2018): Camelina sativa, an oilseed at the nexus between model system and commercial crop. - Plant Cell Rep 37: 1367-138.

[81] Mamolos, A. P., Kalburtji, K. L. (2001): Significance of allelopathy in crop rotation. - J Crop Prod 4: 197-218.

[82] Maqbool, N., Wahid, A., Farooq, M., Cheema, Z. A., Siddique, K. H. M. (2012): Allelopathy and abiotic stress interaction in crop plants. - Allelopathy 451-468.

[83] Matloob, A., Khaliq, A., Farooq, M., Cheema, Z. A. (2010): Quantification of allelopathic potential of different crop residues for the purple nut sedge suppression. Pak J Weed Sci Res 16: 1-12.

[84] Meynard, J. M., Charrier, F., Fares, M., Le Bail, M., Magrini, M. B., Charlier, A., Messéan, A. (2018): Socio-technical lock-in hinders crop diversification in France. Agron Sustain Dev 38: 54.

[85] Ming, Y., Zhu, Z. J., Li, J., Hu, G. X., Fan, X. M. and Yuan, D. Y. (2020): Allelopathic Effects of Castanea henryi aqueous extracts on the growth and physiology of Brassica pekinensis and Zea mays. - Chem Biodiv. DOI: 10.1002/cbdv.202000135.

[86] Molisch, H. (1937): Der Einfluss einer Pflanze auf die andere - Allelpathie. - Fisher, Jena.

[87] Morales, D., Potlakayala, S., Soliman, M., Daramola, J., Weeden, H., Jones, A., Kovak, E., Lowry, E., Patel, P., Puthiyaparambil, J., Goldman, S. (2017): Effect of biochemical and physiological response to salt stress in Camelina sativa. - Commun Soil Sci Plant Ana 48: 716-729.

[88] Naranjo, S. E., Ellsworth, P. C., Dierig, D. A. (2011): Impact of Lygus spp. (Hemiptera: Miridae) on damage, yield and quality of Lesquerella (Physaria fendleri), a potential new oil-seed crop. - J Eco Ento 104: 1575-1583.

[89] Naranjo, S. E., Stefanek, M. A. (2012): Feeding behavior of a potential insect pest, Lygus hesperus, on four new industrial crops for the arid southwestern USA. - Ind Crops Prod 37: 358-361.

[90] Naseem, M., Aslam, M., Ansar, M., Azhar, M. (2010): Allelopathic effects of sunflower water extract on weed control and wheat productivity. - Pak J Weed Sci Res15: 107-116.

[91] Nawaz, A., Farooq, M., Cheema, S. A., Cheema, Z. A. (2014): Role of allelopathy in weed management. - Recent Advances in Weed Management. DOI: 10.1007/978-14939-1019-9_3.

[92] Nawaz, A., Sarfraz, M., Sarwar, M., Farooq, M. (2018): Ecological Management of Agricultural Pests Through Allelopathy. - Mérillon, J.-M., Ramawat, K. G. (eds.) Coevolution of Secondary Metabolites. Springer, Cham, pp. 1-33. DOI: 10.1007/978-3-31976887-8_17-1.

[93] Obour, A. K., Sintim, H. Y., Obeng, E. et al. (2015): Oilseed camelina (Camelina sativa L Crantz): production systems, prospects and challenges in the USA great plains. - Adv Plants Agric Res 2: 68-76.

[94] Olivier, C., Séguin-Swartz, G., Galka, B., Olfert, O. (2011): Aster yellows in leafhoppers and field crops in Saskatchewan, Canada, 2001-2008. - Am J Plant Sci Biotechnol 141: 425-462.

[95] Pavlista, A. D., Hergert, G. W., Margheim, J. M., Isbell, T. A. (2016): Growth of spring Camelina (Camelina sativa) under deficit irrigation in western Nebraska. - Ind Crops Prod 83: 118-123. 
[96] Ponnampalam, E. N., Kerr, M. G., Butler, K. L., Cottrell, J. J., Dunshea, F. R., Jacobs. J. L. (2019): Filling the out of season gaps for lamb and hogget production: diet and genetic influence on carcass yield, carcass composition and retail value of meat. - Meat Sci 148: 156-163.

[97] Prithiviraj, B., Perry, L. G., Badri, D. V., Vivanco, J. M. (2007): Chemical facilitation and induced pathogen resistance mediated by a root-secreted phytotoxin. - New Phytol 173: 852-860.

[98] Rahman, M. J., de Camargo, A. C., Shahidi. F. (2018): Phenolic profiles and antioxidant activity of defatted camelina and Sophia seeds. - Food Chem 240: 917-925.

[99] Rawat, L. S., Maikhuri, R. K., Bahuguna, Y. M., Jha, N. K., Phondani, P. C. (2017): Sunflower allelopathy for weed control in agriculture systems. - J Crop Sci Biotechnol 20: 45-60.

[100] Razzaq, A., Cheema, Z. A., Jabran, K., Farooq, M., Khaliq, A., Haider, G., Basra, S. M. A. (2010): Weed management in wheat through combination of allelopathic water extract with reduced doses of herbicides. - Paki J Weed Sci Res 16: 247-256.

[101] Rizzitello, R., Zhang, C. J., Auer, C. (2019): Camelina (Camelina sativa L. Crantz) Crop performance, insect pollinators, and pollen dispersal in the northeastern US. - bioRxiv. DOI: https://doi.org/10.1101/756619.

[102] Russo, V., Bruton, B., Sams, C. (2010): Classification of temperature response in germination of Brassicas. - Ind Crops Prod 31: 48-51.

[103] Sagun, V. G., Auer, C. (2017): Pollen morphology of selected Camelineae (Brassicaceae). - Palynol 41: 255-266.

[104] Saucke, H., Ackermann, K. (2006): Weed suppression in mixed cropped grain peas and false flax (Camelina sativa). - Weed Res 46: 453-461.

[105] Saudy, H. S. (2015): Maize cowpea intercropping as an ecological approach for nitrogen use rationalization and weed suppression. - Arch Agron Soil Sci 61: 1-14.

[106] Schillinger, W. F., Wysocki, D. J., Chastain, T. G., Guy, S. O., Karow, R. S. (2012): Camelina: planting date and method effects on stand establishment and seed yield. - Field Crops Res 130: 138-144.

[107] Schreiber, M. M. (1992): Influence of tillage, crop rotation and weed management on grain foxtail (Setaria faberi) population dynamics and corn yield. - Weed Sci 40: 645653.

[108] Scottish Rural Colleges (2013): Camelina: physical requirements. http://www.sruc.ac.uk/info/120186/novel_and_non-food_crops/ 166/camelina/3.

[109] Séguin-Swartz, G., Eynck, C., Gugel, R., Strelkov, S., Olivier, C., Li, J., Klein-Gebbinck, H., Borhan, H., Caldwell, C., Falk, K. (2009): Diseases of Camelina sativa (falseflax). Cand J Plant Pathol 31: 375-386.

[110] Sobiech, Ł., Grzanka, M., Kurasiak-Popowska, D., Radzikowska, D. (2020): Phytotoxic effect of herbicides on various Camelina [Camelina sativa (L.) Crantz] genotypes and plant chlorophyll fluorescence. - Agric 10: 185.

[111] Sodaeizadeh, H., Hosseini, Z. (2012): Allelopathy: an environmentally friendly method for weed control. - International Conference on Applied Life Sciences (ICALS2012), Turkey, September 10-12.

[112] Soroka, J., Olivier, C., Grenkow, L., Séguin-Swartz, G. (2015): Interactions between Camelina sativa (Brassicaceae) and insect pests of canola. - Canad Entomol 147: 193214.

[113] Sun, C., Cao, H., Shao, H., Lei, X., Xiao, Y. (2011): Growth and physiological responses to water and nutrient stress in oil palm. - Afric J Biotechnol 10: 10465-10471.

[114] Tabatabaie, S. M. H., Murthy, G. S. (2017): Effect of geographical location and stochastic weather variation on life cycle assessment of biodiesel production from camelina in the northwestern USA. - Int J Life Cycl Assess 22: 867-882.

[115] Taiz, L. and Zeiger, E. (2010): Plant Physiology. 5th Ed. - Sinauer Associates, Sunderland, MA. https://www.sinauer.com/media/wysiwyg/tocs/PlantPhysiology5.pdf. 
[116] Teasdale, J. R., Mohler, C. L. (2000): The quantitative relationship between weed emergence and the physical properties of mulches. - Weed Sci 48: 385-392.

[117] Tursun, N., Iş1k, D., Demir, Z., Jabran, K. (2018): Use of living, mowed, and soilincorporated cover crops for weed control in apricot orchards. - Agron 8: 150.

[118] Voll, E., Franchini, J. C., Tomazon, R., Cruz, D., Gazziero, D. L., Brighenti, A. M. (2004): Chemical interactions of Brachiaria plantaginea with Commelina bengalensis and Acanthospermum hispidum in soybean cropping systems. - J Chem Ecol 30: 1467-1475.

[119] Wang, Y., Frei, M. (2011): Stressed food - the impact of abiotic environmental stresses on crop quality. - Agric Eco Environ 141: 271-286.

[120] Wang, C., Wu, B., Jiang, K. (2019): Allelopathic effects of Canada goldenrod leaf extracts on the seed germination and seedling growth of lettuce reinforced under salt stress. - Ecotoxicol 28: 103-116.

[121] Waraich, E. A., Ahmed, Z., Ahmad, R., Saifullah, Shahbaz, M., Ehsanullah. (2016): Modulation in growth, development, and yield of Camelina sativa by nitrogen application under water stress conditions. - J Plant Nut 40: 726-735.

[122] Waraich, E. A., Ahmed, Z., Ahmad, R., Shabbir, R. N. (2017): Modulating the phenology and yield of camelina sativa L. by varying sowing dates under water deficit stress conditions. - Soil Environ 36: 84-92.

[123] Waśkiewicz, A., Muzolf-Panek, M., Goliński, P. (2013): Phenolic Content Changes in Plants under Salt Stress. - In: Ahmad, P. et al. (eds.) Ecophysiology and Responses of Plants under Salt Stress. Springer, New York, pp. 283-314. DOI: 10.1007/978-1-46144747-4_11.

[124] Ye, S. F., Zhou, Y. H., Sun, Y., Zou, L. Y., Yu, J. Q. (2006): Cinnamic acid causes oxidative stress in cucumber roots, and promotes incidence of Fusarium wilt. - Environ Experi Bot 56: 255-262.

[125] Yohannes, G., Kidane, L., Beyene, T. (2020): Effect of salt stresses on seed germination and early seedling growth of Camelina sativa L. - Ethiop J Sci 12: 1-19.

[126] Yuan, L., Li, R. (2020): Metabolic engineering a model oilseed Camelina sativa for the sustainable production of high-value designed oils. - Front Plant Sci 11. DOI: 10.3389/fpls.2020.00011.

[127] Zhang, C. J., Auer, C. (2019): Overwintering assessment of Camelina (Camelina sativa) cultivars and congeneric species in the northeastern US. - Ind Crops Prod 139: 111532.

[128] Zhang, C. J., Auer, C. (2020): Hybridization between Camelina sativa (L.) Crantz and common Brassica weeds. - Ind Crops Prod 147: 112240. 